Qifeng Yang • Goro Yoshimura • Ichiro Mori

Takeo Sakurai • Kennichi Kakudo

\title{
Chromosome 3p and breast cancer
}

Received: April 30, 2002 / Accepted: May 27, 2002

\begin{abstract}
Solid tumors in humans are now believed to develop through a multistep process that activates oncogenes and inactivates tumor suppressor genes. Loss of heterozygosity at chromosomes 3p25, 3p22-24, 3p21.3, $3 \mathrm{p} 21.2-21.3,3 \mathrm{p} 14.2,3 \mathrm{p} 14.3$, and $3 \mathrm{p} 12$ has been reported in breast cancers. Retinoid acid receptor $\beta 2$ (3p24), thyroid hormone receptor $\beta 1$ (3p24.3), Ras association domain family $1 \mathrm{~A}$ (3p21.3), and the fragile histidine triad gene (3p14.2) have been considered as tumor suppressor genes (TSGs) for breast cancers. Epigenetic change may play an important role for the inactivation of these TSGs. Screens for promoter hypermethylation may be able to identify other TSGs in chromosome $3 \mathrm{p}$. Alternatively, use of an "epigenetic modifier" may enhance the response to another type of agent for breast cancer.
\end{abstract}

Key words Breast cancer - Chromosome $3 p \cdot$ Loss of heterozygosity · Hypermethylation - RAR $\beta 2$ - TR $\beta 1$. RASSF1 $\cdot$ FHIT

\section{Introduction}

Breast cancer is one of the most common malignancies among women, and its cumulative risk by age 85 years is 1 in 8 women in the United States and 1 in 40 women in Japan (American Cancer Society 1994). Solid tumors in humans

Q. Yang

Department of General Surgery, Qilu Hosptial, Shandong

University, Ji'nan, Shandong Province, People's Republic of China

Q. Yang · G. Yoshimura · T. Sakurai

Department of Surgery, Affiliated Kihoku Hospital, Wakayama

Medical University School of Medicine, Wakayama, Japan

Q. Yang $(\bowtie) \cdot$ I. Mori $\cdot$ K. Kakudo

Second Department of Pathology, Wakayama Medical University

School of Medicine, 811-1 Kimiidera, Wakayama 641-8509, Japan

Tel. +81-73-441-0635; Fax +81-73-446-4825

e-mail: yang-qf@mail.wakayama-med.ac.jp are now believed to develop through a multistep process that activates oncogenes and inactivates tumor suppressor genes (Lopez-Otin and Diamandis 1998). Inactivation of a tumor suppressor gene (TSG) often involves mutation of one allele and loss or replacement of a chromosomal segment containing another allele. Loss of heterozygosity $(\mathrm{LOH})$ has been found on chromosomes 1p, 1q, 3p, 6q, 7p, $11 \mathrm{q}, 13 \mathrm{q}, 16 \mathrm{q}, 17 \mathrm{p}, 17 \mathrm{q}, 18 \mathrm{p}, 18 \mathrm{q}$, and 22q in breast cancer (Smith et al. 1993; Callahan et al. 1992; Sato et al. 1990; Hirano et al. 2001a); the commonly deleted regions include 3p, 6q, 7p, 11q, 16q, and 17p (Smith et al. 1993; Hirano et al. 2001a). In addition, other gross alterations such as the aneuploidy state and gene amplification, and small changes including point mutations, small insertions, or deletions in multiple genes are scattered through the genome of cancer cells. In fact, most cancer research on the neoplastic cell in the last 20 years has focused on genetic aspects. However, the malignant cell has also acquired a different epigenotype. The inheritance of information on the basis of gene expression levels is known as epigenetics, as opposed to genetics, which refers to information transmitted on the basis of gene sequence. The main epigenetic modification in mammals, and in particular in humans, is the methylation of the cytosine nucleotide residue.

DNA methylation is an enzymatic modification performed by DNA methyltransferases. The added methyl group does not affect the base pairing itself, but the protruding of methyl groups into the major groove can affect DNA-protein interactions (Razin and Riggs 1980). In eukaryotes, two different types of DNA methyltransferases have been characterized: de novo methyltransferases, such as Dnmt3a and Dmnt3b (Okano et al. 1998), which use nonmethylated DNA as a subtrate; and maintenance methyltransferases, such as Dnmt1 (Bestor et al. 1988), which methylate hemimethylated DNA that is generated by replication of methylated sites (Bestor 2000). Maintenance methylation implies copying of the existing methylation pattern of the old DNA strand onto the new one. Therefore, DNA methylation can be heritable and can serve as an epigenetic mark that is transmitted by mitotic or cell division onto the progeny. DNA methylation of TSGs is a 
Table 1. LOH, sensitive microsatellite markers, and candidate TSGs in chromosome $3 \mathrm{p}$

\begin{tabular}{|c|c|c|}
\hline Regions of LOH & Microsatellite markers & Candidate TSGs \\
\hline $3 \mathrm{p} 25$ & $\begin{array}{l}\text { D3S1351 } \\
\text { D3S1597 } \\
\text { D3S1111 }\end{array}$ & $V H L$ \\
\hline $3 \mathrm{p} 24$ & $\begin{array}{l}\text { D3S } 1286 \\
\text { D3S } 1293 \\
\text { D3S } 1283 \\
\text { D3S } 2432 \\
\text { D3S } 1537\end{array}$ & $R A R \beta 2, T R \beta 1$ \\
\hline $3 \mathrm{p} 21.3$ & $\begin{array}{l}\text { D3S } 4597 \\
\text { D3S } 4604 \\
\text { D3S } 4614 \\
\text { D3S } 4622 \\
\text { D3S } 4623 \\
\text { D3S } 4624\end{array}$ & $R A S S F 1$ \\
\hline $3 \mathrm{p} 14.2$ & $\begin{array}{l}\text { D3S } 1295 \\
\text { D3S } 1234 \\
\text { D3S } 4103 \\
\text { D3S } 1300 \\
\text { D3S } 1600\end{array}$ & FHIT \\
\hline $3 \mathrm{p} 12$ & $\begin{array}{l}\text { D3S } 1284 \\
\text { D3S } 1274 \\
\text { D3S } 1511\end{array}$ & DUTT1 \\
\hline
\end{tabular}

LOH, Loss of heterozygosity; TSGs, tumor suppressor genes

frequent mechanism of transcriptional silencing in cancer (Jones and Laird 1999; Baylin and Herman 2000). Recently, Rhee et al. (2002) demonstrated that Dnmt1 and Dnmt3b cooperate to silence genes in human cancer cells. The molecular mechanisms underlying the specificity of methylation are largely unknown. Croce et al. (2002) reported that leukemia-promoting promyelocytic leukemia-retinoic acid receptor fusion protein induces gene hypermethylation and silencing by recruiting DNA methyltransferases to target promoters, and that hypermethylation contributes to its leukemogenic potential. Retinoic acid treatment induces promoter demethylation, gene reexpression, and reversion of the transformed phenotype. The mechanistic link between genetic and epigenetic changes during transformation suggests that hypermethylation contributes to the early steps of carcinogenesis (Croce et al. 2002).

Chromosome $3 p$ allele loss is a frequent event in breast cancer, and some candidate TSGs have been located in this region (Table 1). Notably, epigenetic changes can mediate inactivation of these TSGs (Bovenzi et al. 1999; Sirchia et al. 2000; Widschwendter et al. 2000; Li et al. 2002; Dammann et al. 2001; Zochbauer-Muller et al. 2001). We would like to outline the genetic and epigenetic analysis of chromosome $3 \mathrm{p}$ in breast cancer.

\section{LOH analysis of chromosome 3p}

$\mathrm{LOH}$ at chromosome $3 \mathrm{p}$ occurs in many human malignancies including breast cancers (Ali et al. 1989; Devilee et al.
1989). It is important to elucidate the region within $3 p$ that is involved in breast cancer, which could provide information on genetic alterations in tumors and help to localize sites of potential TSGs. Ali et al. (1989) reported a 30\% LOH of markers at 3p21-25. Sato et al. (1990) reported $\mathrm{LOH}$ at $3 p$ in $47 \%$ of 219 tumors analyzed by restriction fragment length polymorphism. Matsumoto et al. (1997) reported a frequency of 52\% 3p LOH in 196 tumors analyzed by conventional allelotyping. Maitra et al. (2001) performed high-resolution allelotyping for $\mathrm{LOH}$ analysis on microdissected samples from 45 primary breast cancers; allele loss in some regions of chromosome $3 \mathrm{p}$ was detected in 39 cases (87\%). Chen et al. (1994) demonstrated that two separate deletion regions (3p13-14 and 3p24-26) existed on chromosome 3p. Mastumoto et al. (1997) were able to define two noncontiguous regions of frequent $\mathrm{LOH}$ in their analysis (3p24.3-25.1 and 3p14.2-21.1). Maitra et al. (2001) revealed frequent $\mathrm{LOH}$ in $3 \mathrm{p} 21.3$, 3p22-24, 3p21.2-21.3, 3p25, 3p14.2, 3p14.3, and 3p12.

The chromosomal regions where allelic losses have been detected are thought to include specific target genes whose inactivation either is essential for transformation or provides a selective advantage associated with progression. However, it is also possible for an $\mathrm{LOH}$ to be randomly acquired and irrelevant but coselected with other specific mutations important for tumor development. It is still tempting to speculate that these discrete areas in chromosome $3 \mathrm{p}$ may harbor one or more TSGs critical to breast carcinogenesis.

\section{Candidate tumor suppressor genes in chromosome 3p}

\section{Retinoid acid receptor $\beta 2$}

Retinoid acid receptor $\beta 2$ (RAR $\beta 2$ ) maps to chromosome 3p24 (Chambon 1996), a region that exhibits a high frequency of LOH (Deng et al. 1996). Deng et al. (1996) reported that $\mathrm{LOH}$ in normal terminal ductal-lobular units adjacent to the tumor was seen in six of the ten cases with confirmed LOH at 3p24 in the cancer. Maitra et al. (2001) detected 3p24 LOH in precursor lesions. Retroviral transduction of breast tumor cell lines with RAR $\beta 2$ results in inhibition of tumor cell proliferation (Seewaldt et al. 1995). RAR $\beta 2$ levels were found to be decreased or suppressed in a number of malignant tumors, including lung cancer, squamous cell cancer of the head and neck, and breast cancer (Picard et al. 1999; Xu et al. 1997, 1999). These findings suggest that $\operatorname{RAR} \beta 2$ plays an important role in limiting the growth of many cell types, and that the loss of this regulatory activity is associated with tumorigenesis. RAR $\beta 2$ inhibits the metastatic cascade in a mouse mammary gland xenograft tumor model and is a potential candidate for therapeutic intervention in human breast cancer (Treutin et al. 2002). RAR $\beta 2$ can mediate retinoid action in breast cancer cells by promoting apoptosis (Liu et al. 1996). In vitro (Liu et al. 1996) and in vivo (Toma et al. 2000) 
studies suggest that RAR $\beta 2$ could be induced by alltrans-retinoic acid in breast cancer. All-trans- $N$-(4hydroxyphenyl)retinamide (4HPR), a synthetic retinoid acid, is an activator of RAR $\beta 2$. 4HPR is a promising drug for the chemoprevention of breast cancer (Fisher et al. 1998). This synthetic retinoid has been shown to be more effective and less toxic than other retinoids for chemoprevention of mammary cancer in animals (Moon et al. 1979). 4HPR was the subject of a recent 5-year clinical trial conducted to assess its usefulness in preventing contralateral breast cancer in a population of patients previously operated on for breast cancer (Veronesi et al. 1999). The combined administration of tamoxifen and 4HPR has proven to be additive or synergistic in both the growth inhibition of the breast cancer cell line MCF-7 and the prevention of $N$-methyl- $N$ nitrosourea-induced mammary carcinoma in the rat (Ratko et al. 1989). Because retinoids do not require estrogen receptors (ERs) for their action, they may affect neoplastic transformation in ER-negative cells (Fraker et al. 1984), in contrast to tamoxifen, whose primary mechanism of action is through the ER.

To understand why RAR $\beta 2$ activity is down-regulated or lost in malignant tumors, researchers have made intense efforts to identify possible alterations that affect either the RAR $\beta 2$ promoter or its regulatory factors (Seewaldt et al. 1995; Xu et al. 1997; Wu et al. 1997). We assessed LOH on chromosome band 3 p24 to correlate it with RAR $\beta 2$ expression and other established prognostic parameters in primary breast cancers (Yang et al. 2001a). Based on three microsatellites, D3S 1283, D3S 1293, and D3S 1286, all of the tumors were informative; of these, 12 (23\%) exhibited LOH. RAR $\beta 2$ expression was lost in $42 \%$ (19/45) of detected samples. We found that $\mathrm{LOH}$ on chromosome band 3 p24 was not correlated with loss of RAR 32 . Moreover, no mutations were found in the promoter of breast cancer (Widschwendter et al. 1997; Yang et al. 2001b). These results suggest that it is unlikely that changes in gene structure could completely explain the altered RAR $\beta 2$ expression. A possible mechanism to be considered is suppression of the RAR $\beta 2$ gene by methylation in the promoter (Bovenzi et al. 1999; Sirchia et al. 2000; Widschwendter et al. 2000). We demonstrated that biallelic inactivation of the RAR $\beta 2$ gene could result either from epigenetic inactivation of both parental alleles, or from epigenetic modification of one allele and deletion of the remaining allele (Yang et al. 2001b). Unexpectedly, methylation status could not account completely for suppression of RAR $\beta 2$ expression in breast cancer tumors (Widschwendter et al. 2000; Yang et al. 2001c). Changes altering RAR $\beta 2$ transcription in breast cancer might be prevented in the presence of supraphysiological levels of retinoic acid. This hypothesis was supported by the findings that RAR $\beta 2$ expression is selectively reduced in several organs when vitamin $\mathrm{A}$ is deficient, and is enhanced by retinoic acid (Kato et al. 1992; Verma et al. 1992). In addition, transcription of RAR $\beta 2$ is also regulated by corepressors and coactivators; thus, its suppression may be due to aberrant expression of these cofactors. Previous studies have indicated that orphan receptor chicken ovalbumin upstream promoter transcription factor is required for in- duction of RAR $\beta 2$ in several types of cancer cells including the breast (Lin et al. 2000).

Thyroid hormone receptor $\beta 1$

Our findings that $\mathrm{LOH}$ of the $3 \mathrm{p} 24$ region harboring the RAR $\beta 2$ gene does not correlate with lack of RAR $\beta 2$ expression may indicate that other genes of these regions, probably not only $R A R \beta 2$, play a role in determining the pathological characteristics of the tumors (Yang et al. 2001a). The frequent region of allelic loss at 3p24.3 in morphologically normal terminal ductal-lobular units also encompasses the thyroid hormone receptor $\beta 1$ (TR $\beta 1)$ gene (Deng et al. 1996; Li et al. 1997). TR $\beta 1$ regulates gene expression when bound to thyroid response elements in the proximity of target genes (Mangelsdorf et al. 2000). On the basis of the presence or absence of the ligand, thyroid hormone triiodothyronine $\left(\mathrm{T}_{3}\right), T R \beta 1$ can act as a transcriptional activator or silencer (Damm et al. 1989). Increasing evidence has suggested that aberrant expression and/or mutations in TR genes could be associated with carcinogenesis. A reduction in the expression of mRNA for $T R \beta 1$ and $T R \beta 2$ was implicated in inappropriate expression of the glycoprotein hormone $\alpha$-subunit gene in nonfunctioning tumors of the anterior pituitary and was proposed to contribute to uncontrolled tumor growth (Gittoes et al. 1997; McCabe et al. 1999). Reduced expression of $T R \beta 1$ was also found in poorly differentiated fibroblast-like osteosarcoma (Williams et al. 1994). However, in poorly differentiated hepatocarcinomas, overexpression of $T R \beta 1$ was correlated with enhanced $\mathrm{T}_{3}$-induced proliferation (Lin et al. 1990, 1994). In neuroblastoma cells, Lebel et al. (1994) have also demonstrated that $\mathrm{T}_{3}$ treatment of $T R \beta 1$-overexpressing cultures arrests proliferaton in the $\mathrm{G} 0 / \mathrm{G} 1$ phase of the cell cycle, and induces morphological and functional differentiation. These results suggest that aberrant expression of $T R \beta 1$ may be associated with different types of tumors and/ or different states of differentiation. Functionally impaired $\beta 1$ mutants have been detected in thyroid papillary cancer (Puzianowska- Kuznicka). Li et al. (2002) could not detect $T R \beta 1$ mutations but observed a variable degree of $T R \beta 1$ promoter hypermethylation in two of five breast cancer cell lines and in all 11 cases of primary breast cancer examined. Moreover, biallelic inactivation of $T R \beta 1$ by $\mathrm{LOH}$ and/or methylation was also suggested.

\section{Ras association domain family $1 \mathrm{~A}$}

Ras association domain family 1 ( $R A S S F 1)$ maps to chromosome 3p21.3. It spans $7.6 \mathrm{~kb}$ of genomic DNA, has a predicted Ras association domain and homology to the Ras effector Nore 1 (Dammann et al. 2000). The RASSF1 gene encodes two major transcripts, RASSF1A and RASSF1C, which are produced by alternative promoter selection and alternative messenger RNA splicing. RASSF1A is encoded by $R A S S F 1$ exons $1 \mathrm{~A}, 1 \mathrm{C}$, and 2-5. RASSF1C is encoded by RASSF1 exons 1-5. The start sites for RASSF1A and $R A S S F 1 C$ are approximately $2 \mathrm{~kb}$ apart and have two inde- 
pendent $\mathrm{CpG}$ island-containing putative promoter regions. RASSF1A is predicted to encode a $39-\mathrm{kDa}$ peptide that contains an N-terminal diacylglycerol-binding domain and a Ras association domain. RARSSF1A promoter hypermethylation was detected in many breast cancer cell lines and $49 \%-62 \%$ of primary breast cancers (Burbee et al. 2001; Dammann et al. 2001). However, Agathanggelou et al. (2001) reported RASSF1A promoter hypermethylation in $9 \%$ of primary breast cancers; the lower hypermethylation frequency may result from sample selection bias. Burbee et al. (2001) demonstrated that the frequency of RASSF1A gene silencing virtually parallels that of the incidence of the LOH for chromosome 3p21, the region that harbors the gene. Methylation and LOH may be the major loss of function pathways for the RASSF1A gene because somatic mutations appear to be rare in this gene (Dammann et al. 2000). Dammann et al. (2001) detected a constant methylation frequency of $R A S S F 1 A$ in all of the different grades of the mammary cancers. $R A S S F 1 A$ inactivation was already very high in grade I tumors. Furthermore, some methylation is also detected in $7.5 \%$ of the samples, which were classified as normal tissue removed with tumor surgery. Thus, methylation of RASSF1A may be an early event during breast cancer pathogenesis.

The fragile histidine triad gene

The fragile histidine triad (FHIT) gene has been mapped to 3 p14.2 of human chromosome 3 (Ohta et al. 1996). The most common fragile site of the human genome, FRA3B, maps within the FHIT gene (Ohta et al. 1996). The presence of the FRA3B fragile site within FHIT suggests that the fragility of this gene may make FHIT susceptible to rearrangements induced by a variety of environmental carcinogens. It also suggests that the degree of chromosomal fragility at this site may contribute to the degree of cancer susceptibility. In sporadic breast cancer, LOH within the FHIT gene has been observed at different frequencies (Ahmadian et al. 1997; Man et al. 1996; Ingvarsson et al. 1999; Huiping et al. 2000; Yang et al. 2002). Similar deletions of the FHIT gene have been observed in preneoplastic lesions (Ahmadian et al. 1997), suggesting that FHIT deletions could be an early event in a significant fraction of breast cancer. $\mathrm{LOH}$ at FHIT is associated with tumor progression and patient survival (Ingvarsson et al. 2001). Gatalica et al. (2000) have demonstrated that the expression of Fhit protein is related inversely to disease progression in patients with breast cancer. Campiglio et al. (1999) analyzed Fhit expression in 185 breast cancers and indicated that a decrease or an absence of Fhit protein expression is associated with high proliferation and large tumor size. We assessed Fhit expression using immunohistochemistry in 166 invasive breast cancers (Yang et al. 2001d) and found that loss of Fhit expression is associated with higher malignant phenotypes and appears to be a prognostic factor in breast cancer.

Previous studies have demonstrated that point mutations are very infrequent in FHIT (Ahmadian et al. 1997;
Gonzalez et al. 1998; Kannan et al. 2000). Hypermethylation seems to play an important role in FHIT inactivation (Zochbauer-Muller et al. 2001).

\section{Discussion and future directions}

In addition to the candidate TSGs described earlier, DUTT1 (3p12) may be a new candidate TSG for breast cancer (Sundaresan et al. 1998). Its tumor-suppressing activity and protein patterns in tumors are unknown. Chromosome 3p25 has been reported to have a significantly adverse effect on postoperative survival (Matsumoto et al. 1999; Hirano et al. 2001a, 2001b). Lininger et al. (1999) also suggest that TSG in this region contributes to carcinogenesis of apocrine cancer of the breast. The Von Hippel Lindau (VHL) gene may be a candidate. Kim et al. (1998) have demonstrated that $V H L$ controls cell cycle progression by regulation of p27Kip1 at both the mRNA and protein levels. However, no mutations were identified in the $V H L$ gene regions studied in breast cancer cell lines (Bailly et al. 1995). It is possible that the $V H L$ gene or another putative TSG also undergoes inactivation by the increasingly apparent epigenetic pathway of promoter methylation rather than by mutation, but this remains to be determined. Identification of nested 3p21.3 homozygous deletions in small cell lung cancers and a breast cancer line directed positional cloning efforts to a $630-\mathrm{kb}$ region, which was narrowed subsequently to a $120-\mathrm{kb}$ subregion by a breast cancer homozygous deletion (Lerman and Minna 2000; Sekido et al. 1998). A group of candidate tumor suppressor genes (designated CACNA2D2, PL6, 101F6, NPRL2, $B L U, R A S S F 1$, FUS1, HYAL2, and HYAL1) has been identified in a 120 -kb critical tumor homozygous deletion region (found in lung and breast cancers) of human chromosome 3p21.3. The RASSF1A isoform of the RASSF1 gene, which has been studied extensively for promoter methylation in a variety of tumors, including lung and breast cancer, was found to be frequently epigenetically inactivated in these tumors, and shows the ability to suppress lung cancer malignant growth (Burbee et al. 2001; Dammann et al. 2000). Ji et al. (2002) studied the effects of six of these 3p21.3 genes (101F6, NPRL2, BLU, FUS1, HYAL2, and $H Y A L 1)$ on tumor cell proliferation and apoptosis in human lung cancer cells by recombinant adenovirus-mediated gene transfer in vitro and in vivo. They found that forced expression of wild-type FUS1, 101F6, and NPRL2 genes significantly inhibited tumor cell growth by induction of apoptosis and alteration of cell cycle processes. Further research should be addressed if these genes are TSGs for breast cancer.

Frequent hypermethylation has been identified in the TSGs on chromosome 3p (Yang et al. 2001b; Bovenzi et al. 1999; Sirchia et al. 2000; Widschwendter et al. 2000; Li et al. 2002; Dammann et al. 2000; Burbee et al. 2001; Dammann et al. 2001; Zochbauer-Muller et al. 2001). It will be interesting to investigate whether this methylation occurs as part of the aging process, a phenomenon that has been described 
for other genes (Ahuja et al. 1998). Hypermethylation and $\mathrm{LOH}$ may be the major loss of function pathways for these TSGs because somatic mutations appear to be rare, and the mechanisms fit the revised Knudson two-hit theory (Jones and Laird 1999). Similar to LOH (Maitra et al. 2001), hypermethylation also occurs in precursor lesions (Lehmann et al. 2002). This raises the question regarding which event, $\mathrm{LOH}$ or epigenetic change, occurs first in breast cancer development. The development of sporadic breast cancers is driven by heritable phenotypic changes, which are due to both genetic and epigenetic events. Perhaps either one is effective in initiating the disease process. However initiated, the molecular and mechanistic heterogeneity of sporadic cancers suggests that the cause of a tumor may be as specific as the individual in which it has arisen. Therefore, both diagnostic and treatment options need to be tailored to address this aspect.

Epigenetically mediated gene silencing in breast cancer heavily impacts future research in this area. Screens for promoter hypermethylation should be considered as one of the important methods for searching for TSGs in breast cancer. Although heritable, epigenetic changes are potentially reversible. A better understanding of epigenetic regulation of TSGs in gene-specific fashion will help efforts to modulate gene expression selectively, with the ultimate goal of improved breast cancer prevention and therapy.

Acknowledgments Work presented in this review was funded by the 2001 Wakayama Medical Award for Young Researchers (to Dr. Yang), and Grants 014563 (to Dr. Yang), 12770657, and 10045073 from the Minister of Education, Culture, Sports, Science and Technology, Government of Japan. Dr. Yang is deeply indebted to Dr. Akio Kaname (Kaname Clinic, Inosawa Shingu City, Wakayama, Japan).

\section{References}

Agathanggelou A, Honorio S, Macartney D, Martinez A, Dallol A, Rader J, Fullwood P, Chauhan A, Walker R, Shaw JA, Hosoe S, Lerman MI, Minna JD, Maher ER, Latif F (2001) Methylation associated inactivation of RASSF1A from region 3p21.3 in lung, breast and ovarian tumours. Oncogene 20:1509-1518

Ahmadian M, Wistuba II, Fong KM, Behrens C, Kodagoda DR, Saboorian MH, Shay J, Tomlinson GE, Blum J, Minna JD, Gazdar AF (1997) Analysis of the FHIT gene and FRA3B region in sporadic breast cancer, preneoplastic lesions, and familial breast cancer probands. Cancer Res 57:3664-3668

Ahuja N, Li Q, Mohan AL, Baylin SB, Issa JP (1998) Aging and DNA methylation in colorectal mucosa and cancer. Cancer Res 58:54895494

Ali IU, Lidereau R, Callahan R (1989) Presence of two members of cerbA receptor gene family (c-erbA2) in smallest region of somatic homozygosity on chromosome $3 \mathrm{p} 21-25$ in human breast cancer. J Natl Cancer Inst 81:1815-1820

American Cancer Society (1994) Cancer facts and figures. American Cancer Society Atlanta.

Bailly M, Bain C, Favrot MC, Ozturk M (1995) Somatic mutations of von Hippel-Lindau (VHL) tumor-suppressor gene in European kidney cancers. Int J Cancer 63:660-664

Baylin SB, Herman JG (2000) DNA hypermethylation in tumorigenesis: epigenetics joins genetics. Trends Genet 16:168-174

Bestor TH (2000) The DNA methyltransferases of mammals. Hum Mol Genet 9:2395-2402

Bestor TH, Laudano A, Mattaliano R, Ingram V (1988) Cloning and sequencing of a cDNA encoding DNA methyltransferase of mouse cells. J Mol Biol 203:971-983
Bovenzi V, Le NLO, Cote S, Sinnett D, Momparler LF, Momparler RL (1999) DNA methylation of retinoic acid receptor $\beta$ in breast cancer and possible therapeutic role of 5-aza-2'-deoxycytidine. Anticancer Drugs 10:471-476

Burbee DG, Forgacs E, Zochbauer-Muller S, Shivakumar L, Fong K, Gao B, Randle D, Kondo M, Virmani A, Bader S, Sekido Y, Latif F, Milchgrub S, Toyooka S, Gazdar AF, Lerman MI, Zabarovsky E, White M, Minna JD (2001) Epigenetic inactivation of RASSF1A in lung and breast cancers and malignant phenotype suppression. J Natl Cancer Inst 93:691-699

Callahan R, Cropp CS, Merlo GR, Liscia DS, Cappa APM, Lidereau R (1992) Somatic mutations and human breast cancer. Cancer 69:15821588

Campiglio M, Pekarsky Y, Menard S, Tagliabue E, Pilotti S, Croce CM (1999) FHIT loss of function in human primary breast cancer correlates with advanced stage of the disease. Cancer Res 59:3866-3869

Chambon P (1996) A decade of molecular biology of retinoic acid receptors. FASEB J 10:940-954

Chen LC, Matsumura K, Deng G, Kurisu W, Ljung BM, Lerman MI, Waldman FM, Smith HS (1994) Deletion of two separate regions on chromosome 3p in breast cancers. Cancer Res 54:3021-3024

Croce LD, Raker VA, Corsaro M, Faxi F, Fanelli M, Faretta M, Fuks F, Coco FL, Kouzarides T, Nervi C, Minucci S, Pelicci PG (2002) Methyltransferase recruitment and DNA hypermethylation of target promoters by an oncogenic transcription factor. Science 295:10791081

Damm K, Thompson CC, Evans RM (1989) Protein encoded by v-erbA functions as a thyoid-hormone receptor antagonist. Nature 339:593-597

Dammann R, Li C, Yoon JH, Chin PL, Bates S, Pfeifer GP (2000) Epigenetic inactivation of a RAS association domain family protein from the lung tumor suppressor locus 3p21.3. Nat Genet 25:315319

Dammann R, Yang G, Pfeifer GP (2001) Hypermethyaltion of the $\mathrm{CpG}$ island of Ras association domain family $1 \mathrm{~A}$, a putative tumor suppressor gene from the $3 \mathrm{p} 21.3$ locus, occurs in a large percentage of human breast cancers. Cancer Res 61:3105-3109

Deng G, Lu Y, Zlotnikov G, Thor AD, Smith HS (1996) Loss of heterozygosity in normal tissue adjacent to breast cancers. Science 274:2057-2059

Devilee P, van den Broek M, Kuipers-Dijkshoorn N, Kolluri R, Khan PM, Pearson PL, Cornelisse CJ (1989) At least four different chromosomal regions are involved in loss of heterozygosity in human breast cancers. Genomics 5:554-560

Fisher B, Costantino JP, Wickerham DL, Redmond CK, Kavanah M, Cronin WM, Vogel V, Robidoux A, Dimitrov N, Atkins J, Daly M, Wieand S, Tan-Shiu E, Fore L, Wolmark N (1998) Tamoxifen for prevention of breast cancer: report of the National Surgical Adjuvant Breast and Bowel Project P-1 Study. J Natl Cancer Inst 90:1371-1388

Fraker LC, Halter SA, Forbes JT (1984) Growth inhibition by retinol of a human breast carcinoma cell line in vitro and in athymic mice. Cancer Res 44:5757-5763

Gatalica Z, Lele SM, Rampy BA, Norris BA (2000) The expression of Fhit protein is related inversely to disease progression in patients with breast cancer. Cancer 88:1378-1383

Gittoes NJ, McCabe CJ, Verhaeg J, Sheppard MC, Franklyn JA (1997) Thyroid hormone and estrogen receptor expression in normal pituitary and nonfunctioning tumors of the anterior pituitary. J Clin Endocrinol Metab 82:1960-1967

Gonzalez MV, Pello MF, Ablanedo P, Suarez C, Alvarez V, Coto E (1998) Chromosome 3p loss of heterozygosity and mutation analysis of the FHIT and $\beta$-cat genes in squamous cell cancer of the head and neck. J Clin Pathol 51:520-524

Hirano A, Emi M, Tsuneizumi M, Utada Y, Yoshimoto M, Kasumi F, Aiyama F, Sakamoto G, Haga S, Kajiwara T, Nakamura Y (2001a) Allelic losses of loci at 3p25.1, 8p22, 13q12, 17p13.3, and 22q13 correlate with postoperative recurrence in breast cancer. Clin Cancer Res 7:876-882

Hirano A, Utada Y, Haga S, Kajiwara T, Sakamoto G, Kasumi F, Nakamura Y, Emi M (2001b) Allelic losses as prognostic markers for breast cancers. Int J Clin Oncol 6:6-12

Huiping C, Jonasson JG, Agnarson BA, Sigbjornsdottir BI, Huebner $\mathrm{K}$, Ingvarsson S (2000) Analysis of the fragile histidine triad (FHIT) gene in lobular breast cancer. Eur J Cancer 36:1552-1557 
Ingvarsson S, Agnarsson BA, Sigbjornsdottir BI, Kononen J, Kallioniemi OP, Barkardottir RB, Kovatich AJ, Schwarting R, Hauck WW, Huebner K, McCue PA (1999) Reduced Thit expression in sporadic and BRCA2-linked breast cancers. Cancer Res 59:2682-2689

Ingvarsson S, Sigbjornsdottir BI, Huiping C, Jonasson JG, Agnarsson BA (2001) Cancer Detect Prev 25:292-298

Ji L, Nishizaki M, Gao B, Burbee D, Kondo M, Kamibayashi C, Xu K, Yen N, Atkinson EN, Fang B, Lerman MI, Roth JA, Minna JD (2002) Expression of several genes in the human chromosome 3p21.3 homozygous deletion region by an adenovirus vector results in tumor suppressor activities in vitro and in vivo. Cancer Res 62:27152720

Jones PA, Laird PW (1999) Cancer epigenetics comes of age. Nat Genet 21:163-167

Kannan K, Krishnamurthy J, Feng J, Nakajima T, Tsuchida N, Shanmugam G (2000) Mutation prolife of the p53, fhit, p16INK4a/ p19ARF and H-ras genes in Indian breast cancers. Int J Oncol 17:1031-1035

Kato S, Mano H, Kumazwa T, Yoshizuwa Y, Kojima R, Masushige S (1992) Effect of retinoid status on alpha, beta and gamma retinoic acid receptor mRNA levels in various rat tissues. Biochem J 286 : 755-760

Kim M, Katayose Y, Li Q, Rakkar AN, Li Z, Hwang SG, Katayose D, Trepel J, Cowan KH, Seth P (1998) Recombinant adenovirus expressing Von Hippel-Lindau-mediated cell cycle arrest is associated with the induction of cyclin-dependent kinase inhibitor p27Kip1. Biochem Biophys Res Commun 253:672-677

Lebel JM, Dussault JH, Puymirat J (1994) Overexpression of the $\beta 1$ thyroid receptor induces differentiation in neuro-2a cells. Proc Natl Acad Sci USA 91:2644-2648

Lehmann U, Langer F, Feist H, Glockner S, Hasemeier B, Kreipe H (2002) Quantitative assessment of promoter hypermethylation during breast cancer development. Am J Pathol 160:605-612

Lerman MI, Minna JD (2000) The 630-kb lung cancer homozygous deletion region on human chromosome 3p21.3: identification and evaluation of the resident candidate tumor suppressor genes. Cancer Res 60:6116-6133

Li Z, Moore DH, Meng Z, Ljung BM, Gray JW, Dairkee SH (1997) Increased risk of local recurrence is associated with allelic loss in normal lobules of breast cancer patients. Cancer Res 20:268-274

Li Z, Meng ZH, Chandrasekaran R, Kuo WL, Collins CC, Gray JW, Dairkee SH (2002) Biallelic inactivation of the thyroid hormone receptor $\beta 1$ gene in early stage breast cancer. Cancer Res 62:19391943

Lin KH, Shieh HY, Chen SL, Hsu HC (1990) Expression of mutant thyroid hormone nuclear receptors in human hepatocellular carcinoma cells. Mol Carcinog 26:53-61

Lin KH, Lin YW, Parkinson C, Cheng SY (1994) Stimulation of proliferation by $3,3^{\prime}, 5$-triiodo-L-thyronine in poorly differentiated human hepatocarcinoma cells overexpressing $\beta 1$ thyroid hormone receptor. Cancer Lett 85:189-194

Lin B, Chen GQ, Xiao D, Kolluri SK, Cao X, Su H, Zhang XK (2000) Orphan receptor COUP-TF is required for induction of retinoic acid receptor beta, growth inhibition, and apoptosis by retinoic acid in cancer cells. Mol Cell Biol 20:957-970

Lininger RA, Zhuang Z, Man Y, Park WS, Emmert-Buck M, Tavassoli FA (1999) Loss of heterozygosity is detected at chromosomes 1p3536 (NB), 3p25 (VHL), 16p13 (TSC2/PKD1), and 17p13 (TP53) in microdissected apocrine cancers of the breast. Mod Pathol 12:10831089

Liu Y, Lee MO, Wang HG, Li Y, Hashimoto Y, Klaus M, Reed JC, Zhang X (1996) Retinoic acid receptor beta mediates the growthinhibitory effect of retinoic acid by promoting apoptosis in human breast cancer cells. Mol Cell Biol 16:1138-1149

Lopez-Otin C, Diamandis EP (1998) Breast and prostate cancer: an analysis of common epidemiological and biochemical features. Endocr Rev 19:365-396

Maitra A, Wistuba II, Washington C, Virmani AK, Ashfaq R, Milchgrub S, Gazdar AF, Minna JD (2001) High-resolution chromosome $3 p$ allelotyping of breast cancers and precursor lesions demonstrates frequent loss of heterozygosity and a discontinuous pattern of allele loss. Am J Pathol 159:119-130

Man S, Ellis IO, Sibbering M, Blarney RW, Brook JD (1996) High levels of allele loss at the FHIT and ATM genes in non-comedo ductal cancer in situ and grade I tubular invasive breast cancer. Cancer Res 56:5484-5489

Mangelsdorf DJ, Thummel C, Beato M, Herrlich P, Schutz G, Umesono K, Blumberg B, kastner P, Mark M, Chambon P (2000) The nuclear receptor superfamily: the second decade. Cell 83:835839

Matsumoto S, Kasumi F, Sakamoto G, Onda M, Nakamura Y, Emi M (1997) Detailed deletion mapping of chromosome arm 3p in breast cancers: a 2-cM region on 3p14.2-21.1 and 5-cM region on 3p24.325.1 commonly deleted in tumors. Genes Chromosomes Cancer 20:268-274

Matsumoto S, Minobe K, Utada Y, Furukawa K, Onda M, Sakamoto G, Kasumi F, Nakamura Y, Emi M (1999) Loss of heterozygosity at 3p24-p25 as a prognostic factor in breast cancer. Cancer Lett 59:3866-3869

McCabe CJ, Gittoes NJ, Sheppard MC, Franklyn JA (1999) Thyroid receptor alpha 1 and alpha 2 mutations in nonfunctioning pituitary tumors. J Clin Endocrinol Metab 84:649-653

Moon RC, Thompson HJ, Becci JP, Grubbs CH, Gander RJ, Newton DL, Smith JM, Phillips SL, Henderson WR, Mullen LT, Brown CC, Sporn MB (1979) $N$-(4-Hydroxyphenyl) retinamide, a new retinoid for prevention of breast cancer in the rat. Cancer Res 39:13391346

Ohta M, Inoue H, Coticelli MG, Kastury K, Baffa R, Palazzo J, Siprashvili Z, Mori M, McCue P, Druck T, Croce CM, Huebner K (1996) The FHIT gene, spanning the chromosome 3p14.2 fragile site and renal cancer-associated $\mathrm{t}(3 ; 8)$ breakpoint, is abnormal in digestive tract cancers. Cell 84:587-598

Okano M, Xie S, Li E (1998) Cloning and characterization of a family of novel mammalian DNA (cytosine-5) methyltransferases. Nat Genet 19:219-220

Picard E, Seguin C, Monhoven N, Rochette-Egly C, Siat Joelle, Borrelly J, Martinet Y, Martinet N, Vignaud JM (1999) Expression of retinoid receptor genes and proteins in non-small-lung cancer. J Natl Cancer Inst 91:1059-1066

Ratko TA, Detrisac CH, Dinger NM, Thomas CF, Kelloff GJ, Moon RC (1989) Chemopreventive efficacy of combined retinoid and tamoxifen treatment following surgical excision of a primary mammary cancer in female rats. Cancer Res 49:4472-4476

Razin A, Riggs AD (1980) DNA methylation and gene function. Science 210:604-610

Rhee I, Bachman KE, Park BH, Jair K-W, Yen RWC, Schuebel KE, Cui H, Feinberg AP, Lengauer C, Kinzler KW, Baylin SB, Vogelstein B (2002) DNMT1 and DNMT3b cooperate to silence genes in human cancer cells. Nature 416:552-556

Sato T, Tanigami A, Yamakawa K, Akiyama F, Kasumi F, Sakamot G, Nakamura Y (1990) Allelotype of breast cancer: cumulative allele losses promote tumor progression in primary breast cancer. Cancer Res 50:7184-7189

Seewaldt VL, Johnson BS, Parker MB, Collins SJ, Swisshelm K (1995) Expression of retinoic acid receptor beta mediates retinoic acid-induced growth arrest and apoptosis in breast cancer cells. Cell Growth Differ 6:1077-1088

Sekido Y, Ahmadian M, Wistuba II, Latif F, Bader S, Wei MH, Duh FM, Gazdar AF, Lerman MI, Minna JD (1998) Cloning of a breast cancer homozygous deletion junction narrows the region of search for a 3p21.3 tumor suppressor gene. Oncogene 16:3151-3157

Sirchia SM, Ferguson AT, Sironi E, Subramanyan S, Orlandi R, Sukumar S, Sacchi N (2000) Evidence of epigenetic changes affecting the chromatin state of the retinoic acid receptor $\beta 2$ promoter in breast cancer cells. Oncogene 19:1556-1563

Smith H, Lu Y, Deng G, Martinez O, Krams S, Ljung B-M, Thor A, Lagios M (1993) Molecular aspects of early stages of breast cancer progression. J Cell Biochem 17:144-152

Sundaresan V, Chung G, Heppell-Parton A, Xiong J, Grundy C, Roberts I, James L, Cahn A, Bench A, Douglas J, Minna J, Sekido Y, Lerman M, Latif F, Bergh J, Li H, Lowe N, Ogilvie D, Rabbitts P (1988) Homozygous deletions at 3p12 in breast cancer lung cancer. Oncogene 17:1723-1729

Toma S, Raffo P, Nicolo G, Canavese G, Margallo E, Vecchio C, Dastoli G, Iacona I, Regazzi-Bonora M (2000) Biological activity of all-trans-retinoic acid with and without tamoxifen and alphainterferon 2a in breast cancer patients. Int J Oncol 17:991-1000

Treutin PM, Chen LI, Buetow BS, Zeng W, Birkebak TA, Seewaldt VL, Sommer KM, Emond M, Maggio-Price L, Swisshelm K (2002) 
Retinoic acid receptor beta2 inhibition of metastasis in mouse mammary gland xenografts. Breast Cancer Res Treat 72:79-88

Verma AK, Schoemaker A, Simsimm R, Denning M, Zachman RD (1992) Expression of retinoic acid nuclear receptors and tissue transglutaminase is altered in various tissues of rats fed 1 vitamin A-deficient diet. J Nutr 122:2144-2152

Veronesi U, De Palo G, Marubini E, Costa A, Formelli F, Mariani L, Decensi A, Camerini T, Del Turco MR, Di Mauro MG, Muraca MG, Del Vecchio M, Pinto C, D'Aiuto G, Boni C, Campa T, Magni A Miceli R, Perloff M, Malone WF, Sporn MB (1999) Randomized trial of fenretinide to prevent second breast malignancy in women with early breast cancer. J Natl Cancer Inst 91:1847-1856

Widschwendter M, Berger J, Daxenbichler G, Muller-Holzner E, Widschwendter A, Mayr A, Marth C, Zeimet AG (1997) Loss of retinoic acid receptor beta expression in breast cancer and morphologically normal adjacent tissue but not in the normal breast tissue distant from the cancer. Cancer Res 57:4158-4161

Widschwendter M, Berger J, Hermann M, Muller HM, Amberger A, Zeschnigk M, Widschwendter A, Abendstein B, Zeimet AG, Daxenbichler G, Marth C (2000) Methylation and silencing of the retinoic acid receptor $\beta 2$ gene in breast cancer. J Natl Cancer Inst 92:826-832

Williams GR, Bland R, Sheppard MC (1994) Characterization of thyroid hormone (T3) receptors in three osteosarcoma cell lines of distinct osteoblast phenotype: interactions among T3, vitamin D3 and retinoid signalling. Endocrinology 135:2375-2385

Wu Q, Li Y, Liu R, Agadir A, Lee MO, Liu Y, Zhang X (1997) Modulation of retinoic acid sensitivity in lung cancer cells through dynamic balance of orphan receptors nur77 and COUP-TF and their heterodimerization. EMBO J 16:1656-1669

Xu X-C, Sneige N, Liu X, Nandagiri R, Lee JJ, Lukmanji F, Hortobagyi G, Lippman SM, Dhingra K, Lotan R (1997) Progressive decrease in nuclear retinoic acid receptor $\beta$ messenger RNA level during breast carcinogenesis. Cancer Res 57:4992-4996

Xu X-C, Liu X, Tahara E, Lippman SM, Lotan R (1999) Expression and Up-Regulation of retinoic receptor- $\beta$ is associated with retinoid sensitivity and colony formation in esophageal cancer cell lines. Cancer Res 59:2477-2483

Yang Q, Yoshimura G, Sakurai T, Nakamura M, Nakamura Y, Shan L, Suzuma T, Tamaki T, Umemura T, Mori I, Kakudo K (2001a) Allelic loss of chromosome $3 \mathrm{p} 24$ correlates with tumor progression rather than with retinoic acid receptor $\beta 2$ expression in breast cancer. Breast Cancer Res Treat 70:39-45

Yang Q, Mori I, Shan L, Nakamura M, Nakamura Y, Utsunomiya H, Yoshimura G, Suzuma T, Tamaki T, Umemura T, Sakurai T, Kakudo K (2001b) Biallelic inactivation of retinoic acid receptor $\beta 2$ gene by epigenetic change in breast cancer. Am J Pathol 158:299303

Yang Q, Sakurai T, Yoshimura G, Mori I, Nakamura M, Nakamura Y, Suzuma T, Tamaki T, Umemura T, Kakudo K (2001c) Hypermethylation does not account for the frequent loss of the retinoic acid receptor beta 2 in breast cancer. Anticancer Res 21:1829-1833

Yang Q, Yoshimura G, Suzuma T, Tamaki T, Umemura T, Nakamura M, Nakamura Y, Wang X, Mori I, Sakurai T, Kakudo K (2001d) Clinicopathological significance of fragile histidine triad transcription protein expression in breast cancer. Clin Cancer Res 7:38693873

Yang Q, Yoshimura G, Sakurai T, Kakudo K (2002) Fragile histidine triad gene and breast cancer. Med Sci Monit 8 (in press)

Zochbauer-Muller S, Fong KM, Maitra A, Lam S, Geradts J, Ashfaq R, Virmani AK, Milchgrub S, Gazdar AF, Minna JD (2001) 5' CpG island methylation of the FHIT gene is correlated with loss of gene expression in lung and breast cancer. Cancer Res 61:3581-3585 